PRINT ISSN 1119-8362

Electronic ISSN 1119-8362
Full-text Available Online at https://www.ajol.info/index.php/jasem http://ww.bioline.org.br/ja
J. Appl. Sci. Environ. Manage.

Vol. 25 (9) 1569-1573 September 2021

\title{
Microwave Assisted Extraction, Phytochemical and Antimicrobial Evaluation of Ethyl Acetate Extracts of Stem Bark of Ficus exasperata (Vahl)
}

\section{*1UGBENYO, NO; ${ }^{2}$ ANYAM, JN; ${ }^{1}$ YAHAYA, MK; ${ }^{1} \mathrm{HABIB}, \mathrm{LO} ;{ }^{1}$ ABDULSALAM, S}

\author{
${ }^{*}$ Department of Chemistry, Confluence University of Science and Technology, Osara, Kogi State. Nigeria. \\ ${ }^{2}$ Department of Chemistry, Ahmadu Bello University, Zaria, Nigeria. \\ *Corresponding Author Email: ugbenyono@custech.edu.ng
}

\begin{abstract}
Stem bark of Ficus exasperata was extracted using ethyl acetate by microwave-assisted solvent extraction. Phytochemical screening and antimicrobial evaluation were carried out on the extract. Phytochemical screening revealed the presence of cardiac glycosides, tannins, flavonoids, triterpenes and steroids. Antimicrobial evaluation revealed that the extract is active against Methicillin - resistant Staphylococcus aureus (MRSA), Staphylococcus aureus, Streptococcus pneumoniae, Salmonella typhi, Proteus mirabilis, Shigella dysenteriae, Candida stellatoidea and Candida tropicalis. The zones of inhibition $(\mathrm{mm})$ for the test organisms were (24-31) mm. Minimum inhibition concentrations (mg/L) of extract against MRSA, Staphylococcus aureus, Streptococcus pneumonia, Salmonella typhi, Proteus mirabilis, Shigella dysenteriae, Candida stellatoidea and Candida tropicalis were 2.5, 1.25, $1.25,2.5,1.25,1.25,1.25$ and 2.5 respectively. Minimum bactericidal concentrations $(\mathrm{mg} / \mathrm{L})$ of extract against Methicillin - resistant Staphylococcus aureus (MRSA), Staphylococcus aureus, Streptococcus pneumonia, Salmonella typhi, Proteus mirabilis Shigella dysenteriae Candida stellatoidea and Candida tropicalis were 5, 2.5, 2.5, 5, 5, 2.5, 2.5 and 5 respectively. The extract showed high inhibition against MRSA and Candida tropicalis.
\end{abstract}

\section{DOI:https://dx.doi.org/10.4314/jasem.v25i9.4}

Copyright: Copyright (C) 2021 Ugbenyo et al. This is an open access article distributed under the Creative Commons Attribution License (CCL), which permits unrestricted use, distribution, and reproduction in any medium, provided the original work is properly cited.

Dates: Received: 09 May 2021; Revised: 12 August 2021; Accepted: 12 September 2021

Keywords: Antimicrobial evaluation, Ficus exasperata, Minimum Inhibition Concentration, Microwave

One of the most outstanding successes in modern medicine is in the area of the development of Concentration, Microwave antimicrobial agents (Jamuna et al., 2011). Moraceae is a family of flowering plants. The family contains over 500 species of the genus Ficus (Amponsah, 2012). They are mostly found in the tropics and semi-tropics. The genus Ficus consists of woody shrubs which are collectively referred to as fig trees. There are over 45 different species of Ficus in Nigeria (Adebayo et al., 2009). In traditional medicine, Ficus species are used to cure various diseases. For instance, they have been used for the treatment of hypotension, dysentery and as astringents (El-Haway et al., 2012). Ficus exasperata is a medium sized tree or a shrub of about 20 - 30-meter height (Uzama et al., 2018). In Nigeria, the plant is found in secondary rain forest and sometimes besides streams and rivers (Shagal et al., 2011). It is known as forest sandpaper tree (Julius et $a l ., 2020)$. It is known by several vernacular names in Nigeria: Ipin (Yoruba), Inwalinwa (Igbo) (Ughachukwu et al., 2012). It is called Hi-tur in Tiv language and Ijakpi in Igala (Ugbenyo, 2017). Ficus exasperata is used in the treatment of several diseases in African traditional medicine (Nnamonu et. al. 2016). It is used in the treatment of fungal infection, dysentery, itching and rheumatism (Uzama et al., 2018). A decoction of the root of $F$. exasperata is used in the treatment of pneumonia in Tanzania. Its leaves are consumed as vegetable by Edo people of Nigeria (Nnamonu et al. 2016). The leaves are also used as abrasives for polishing furniture and utensils (Amponsa et al., 2013). Cold bark extract of Ficus exasperata is used to treat dizziness. Sap from the bark is used as a remedy for bleeding. The root is used in the treatment of cough, tuberculosis, urinary tract infection and gonorrhoea (Uzama et al., 2018). As a route in discovering antibacterial resistant drugs, microwave assisted extraction of stem bark of Ficus exasperata led to phytochemical screening and antimicrobial evaluation on the crude extracts.

\section{MATERIALS AND METHOD}

Collection and Preparation of Plant Material: Stem bark of Ficus exasperata was collected from Ibaji Local Government of Kogi State (North Central of Nigeria), identified and authenticated at the Herbarium of Department of Biological Sciences, Ahmadu Bello University, Zaria with voucher number 2733. The plant sample was collected, washed with distilled water and dried under shade for three weeks, after 
which it was pulverized and stored at room temperature until the time of extraction.

Microwave Assisted Solvent Extraction: Microwave assisted extraction (MAE) was carried out in line with the method described by Nnamonu et al. (2016). Ethyl acetate was used as solvent for extraction. Pulverized plant sample $(500 \mathrm{~g})$ was extracted with ethyl acetate (1.6 L) for 30 minutes (3 minutes at a time for ten times) using A domestic microwave oven (70 Watts/Defrost function). After extraction, extracts were allowed to cool to room temperature, carefully filtered and subjected to evaporation at room temperature (Muktar et al., 2018).

Phytochemical Screening: Phytochemical screening was carried out to test for presence of the following secondary metabolites: carbohydrates, cardiac glycosides, saponins, tannins, alkaloids, terpenoids, steroids and flavonoid using methods described by Muktar et al. (2018), Idris et al. (2019) and Anyam, (2011).

Test organisms: The bacteria used viz Methicillin resistant Staphylococcus aureus (MRSA), Staphylococcus aureus, Streptococcus pneumoniae, Bacillus cereus, Salmonella typhi, Pseudomonas fluorescens, Proteus mirabilis, Shigella dysenteriae and Proteus vulgaris; and the fungi Candida stellatoidea, Candida tropicalis, and Candida pseudotropicalis were obtained from the Department of Medical Microbiology, Ahmadu Bello University Teaching Hospital Zaria.:

Antimicrobial Screening: Mueller Hinton Agar was the medium used as growth medium for the bacterial and Sabouraud Dextrose agar was used for fungi. The media were prepared according to manufacturer's instruction, sterilized at $121^{\circ} \mathrm{C}$ for 15 minutes, poured into sterile Petri dishes and allowed to cool and solidify. Agar Diffusion method was used for antimicrobial screening of the plant extracts. The sterilized medium was seeded with $0.1 \mathrm{~mL}$ of the standard inoculum of the test microbe, the inoculum was evenly spread over the surface of the medium by use of sterile swab. Using a standard cork borer $(6 \mathrm{~mm}$ in diameter), a well was cut at the centre of each inoculated medium. The solution of the extract $(0.1$ $\mathrm{mL}$ ) of concentration $10 \mathrm{mg} / \mathrm{mL}$ was introduced into each well on the medium.0.1g of extract was dissolved in $10 \mathrm{~mL}$ of DMSO (Dimethyl sulfoxide) to obtain a concentration of $10 \mathrm{mg} / \mathrm{ml}$. This was the initial concentration of the extract used to determine the antimicrobial activities from the plant. Incubation was carried out at $37^{\circ} \mathrm{C}$ for 24 hours for bacteria and at $30^{\circ} \mathrm{C}$ for 7 days for fungi. Each plate of the medium was observed after the stated time for zone of inhibition of growth. Zone of inhibition was measured using a transparent ruler (mm) (Idris et al. 2019).

Minimum Inhibition Concentration (MIC): The extract's minimum inhibitory concentration was determined using the broth dilution method. Mueller Hinton agar and Sabouraud dextrose broth were made as directed by the manufacturer, distributed into test tubes $(10 \mathrm{ml})$, sterilised at $121^{\circ} \mathrm{C}$ for 15 minutes, and allowed to cool. A turbid solution was made using Mcturbidity Farland's standard (scale number 0.5). A sterile test tube was filled with $10 \mathrm{~mL}$ of normal saline solution. The test microorganisms were inoculated and cultured for 6 hours at 37 oC. A microbe broth was diluted in normal saline until the turbidity reached that of the Mc Farland standard, at which point the test microorganisms attained a concentration of around $1.5 \mathrm{x} 108 \mathrm{CFU} / \mathrm{mL}$, as determined by visual comparison. Two times in sterile broth, the extract was serially diluted, providing concentrations of 10 $\mathrm{mg} / \mathrm{mL}, 5 \mathrm{mg} / \mathrm{mL}, 2.5 \mathrm{mg} / \mathrm{mL}, 1.25 \mathrm{mg} / \mathrm{mL}$, and 0.625 $\mathrm{mg} / \mathrm{mL}$. To obtain the starting concentration, the extract $(0.1 \mathrm{~g})$ was dissolved in sterile broth $(10 \mathrm{~mL})$. The microbe suspension in normal saline $(0.1 \mathrm{~mL})$ was injected into various amounts of extract in nutrient broth. For bacteria, the broths were incubated at $37^{\circ} \mathrm{C}$ for 24 hours, and for fungus, at $30^{\circ} \mathrm{C}$ for 7 days. For bacteria, the findings were recorded after 24 hours, and for fungi, after 7 days (Idris et al., 2019).

Minimum Bactericidal Concentration (MBC). Mueller Hinton and Sabouraud dextrose agar were prepared as per manufacturer instruction; sterilised at $121^{\circ} \mathrm{C}$ for 15 minutes, placed into sterile petri dishes, and allowed to cool and harden. The contents of the serial dilution of MIC were then sub-cultured on Mueller Hinton agar for bacteria and Sabouraud dextrose agar for fungi. Bacteria were incubated at $37^{\circ} \mathrm{C}$ for 24 hours and fungi were incubated at $30^{\circ} \mathrm{C}$ for 7 days. The colony growth on each plate was then monitored. The plates with the lowest concentration of the extract without colony growth had the lowest bactericidal/fungicidal concentration (ldris et al., 2019).

\section{RESULTS AND RESULTS}

Extraction of stem bark of Ficus exasperata (500 g) with ethyl acetate using microwave gave a crude extract $(8.9 \mathrm{~g})$, percentage yield was $1.78 \%$. Phytochemical screening revealed the presence of anthraquinones, cardiac glycosides, steroids, triterpenes, and tannins (Table 1). The extracts were found to be effective against Staphylococcus aureus, Streptococcus pneumoniae, Salmonella typhi, Proteus mirabilis, Shigella dysenteriae, Candida stellatoidea, and Candida tropicalis in antimicrobial sensitivity 
testing (Table 2). Minimum Inhibition Concentration of the extract against the test microbes showed the extracts to be effective against MRSA $(2.5 \mathrm{mg} / \mathrm{mL})$, Staphylococcus aureus $(5 \mathrm{mg} / \mathrm{mL})$, Streptococcus pneumoniae $(1.25 \mathrm{mg} / \mathrm{mL})$, Salmonella typhi $(2.5$ $\mathrm{mg} / \mathrm{mL})$, Proteus mirabilis $(1.25 \mathrm{mg} / \mathrm{mL})$, Shigella dysenteriae $(1.25 \mathrm{mg} / \mathrm{mL})$, Candida stellatoidea $(1.25$ $\mathrm{mg} / \mathrm{mL}$ ), and Candida tropicalis $(2.5 \mathrm{mg} / \mathrm{mL})$ (Table
3). Minimum Bactericidal/Fungicidal Concentration of the extract against the test microbes showed the extracts to be effective against MRSA ( $5 \mathrm{mg} / \mathrm{mL})$, Staphylococcus aureus $(2.5 \mathrm{mg} / \mathrm{mL})$, Streptococcus pneumoniae $(2.5 \mathrm{mg} / \mathrm{mL})$, Salmonella typhi (5 $\mathrm{mg} / \mathrm{mL})$, Proteus mirabilis (5 $\mathrm{mg} / \mathrm{mL})$, Shigella dysenteriae $(2.5 \mathrm{mg} / \mathrm{mL})$, Candida stellatoidea $(2.5$ $\mathrm{mg} / \mathrm{mL})$, and Candida tropicalis $(5 \mathrm{mg} / \mathrm{mL})$ (Table 4).

Table 1: Phytochemical screening result

\begin{tabular}{cllll}
\hline S/N & Phytochemical & Test & Observation & Conclusion \\
\hline 1 & Carbohydrate & Fehling test & No change & - \\
2 & Anthraquinone & & Pink colouration & + \\
3 & Cardiac Glycosides & Kella-Killiani Test & Brown ring & + \\
4 & Steroid & Liberman- Burchard test & A colour change from violet to green & + \\
5 & Triterpenes & Salkowski's Test & Redish-brown & + \\
6 & Alkaloids & Dragendorff's test & No change & - \\
& & Meyer' test & No change & No change \\
& & Wagner's test & Green coloration & + \\
7 & Tannins & FeCl $_{3}$ test & Keys: $+=$ Present $-=$ Absent
\end{tabular}

Table 2: Sensitivity/ Zone of inhibition ( $\mathrm{mm}$ ) of Extract Compared with Standards (Control Drugs).

\begin{tabular}{llll}
\hline Test Organism & Crude extract & Ciprofloxacin & Fluconazole \\
\hline MRSA & $\mathrm{S}(27)$ & $\mathrm{R}(0)$ & $\mathrm{R}(0)$ \\
Staphylococcus aureus & $\mathrm{S}(30)$ & $\mathrm{S}(37)$ & $\mathrm{R}(0)$ \\
Streptococcus pneumoniae & $\mathrm{S}(31)$ & $\mathrm{S}(38)$ & $\mathrm{R}(0)$ \\
Bacillus cereus & $\mathrm{R}(0)$ & $\mathrm{S}(38)$ & $\mathrm{R}(0)$ \\
Salmonella typhi & $\mathrm{S}(26)$ & $\mathrm{S}(42)$ & $\mathrm{R}(0)$ \\
Pseudomonas fluorescens & $\mathrm{R}(0)$ & $\mathrm{R}(0)$ & $\mathrm{R}(0)$ \\
Proteus mirabilis & $\mathrm{S}(27)$ & $\mathrm{S}(32)$ & $\mathrm{R}(0)$ \\
Shigella dysenteriae & $\mathrm{S}(29)$ & $\mathrm{S}(41)$ & $\mathrm{R}(0)$ \\
Proteus vulgaris & $\mathrm{R}(0)$ & $\mathrm{S}(30)$ & $\mathrm{R}(0)$ \\
Candida stellatoidea & $\mathrm{S}(29)$ & $\mathrm{R}(0)$ & $\mathrm{S}(34)$ \\
Candida tropicalis & $\mathrm{S}(24)$ & $\mathrm{R}(0)$ & $\mathrm{S}(35)$ \\
Candida pseudotropicalis & $\mathrm{R}(0)$ & $\mathrm{R}(0)$ & $\mathrm{S}(32)$ \\
\hline
\end{tabular}

$\boldsymbol{R}=$ Resistant $\boldsymbol{S}=$ Sensitive. Figures in bracket represent average triplicate zone of inhibition (in $\mathrm{mm}$ ).

Table 3: Minimum Inhibition Concentration of the Extract against the test Organism

\begin{tabular}{|c|c|c|c|c|c|}
\hline Test Organism/Concentration $(\mathrm{mg} / \mathrm{mL})$ & $\stackrel{\varrho}{\text { ف }}$ & 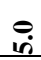 & $\stackrel{\text { In }}{\text { in }}$ & ֻั) & ஸै \\
\hline MRSA & - & - & $0 *$ & + & ++ \\
\hline Staphylococcus aureus & - & - & - & $0 *$ & + \\
\hline Streptococcus pneumoniae & - & - & - & $0 *$ & + \\
\hline Bacillus cereus & & & & & \\
\hline $\begin{array}{l}\text { Salmonella typhi } \\
\text { Pseudomonas fluorescens }\end{array}$ & - & - & $0 *$ & + & ++ \\
\hline Proteus mirabilis & - & - & - & $0 *$ & + \\
\hline $\begin{array}{l}\text { Shigella dysenteriae } \\
\text { Proteus vulgaris }\end{array}$ & - & - & - & $0 *$ & + \\
\hline Candida stellatoidea & - & - & - & $0 *$ & + \\
\hline $\begin{array}{l}\text { Candida tropicalis } \\
\text { Candida pseudotropicalis }\end{array}$ & - & - & $0 *$ & + & ++ \\
\hline
\end{tabular}

Phytochemical Screening: Result of phytochemical screening showed presence of cardiac glycosides, tannins, flavonoids, anthraquinones, steroids and triterpenes. Lawal et al., (2012) reported the presence of saponins and cardiac glycosides with traces of anthraquinone in methanolic root bark extracts of the plant. Similarly, Shagal et al., (2011) reported the presence of tannins, flavonoids, saponins, glycosides, phenols and steroids from water and ethanolic extracts of leaves, stembark and roots of the plant. These phytochemicals have a wide range of therapeutic effects. Cardioactive substances, such as cardiac glycosides, affect the heart muscles and stimulate renal flow, which is a critical homeostatic mechanism that protects the kidney from arterial pressure spikes that would otherwise cause harm to the glomerular capillaries. They affect neurons, affecting the mechanical and electrical activity of the heart, as well as the vascular system's resistance and capacitance. (Lawal et al., 2012). Tannins are known for their use 
in preventing urinary tract infections and other bacterial infections (Noce et al., 2021). The presence of flavonoids in a plant indicates that natural phenolic compounds which have beneficial effects in human diet as antioxidant and neutralizing agent for free radicals are contained in the plant (Suleman et al., 2019).

Table 4: Minimum Bactericidal/Fungicidal Concentration of the Extract against test Organisms

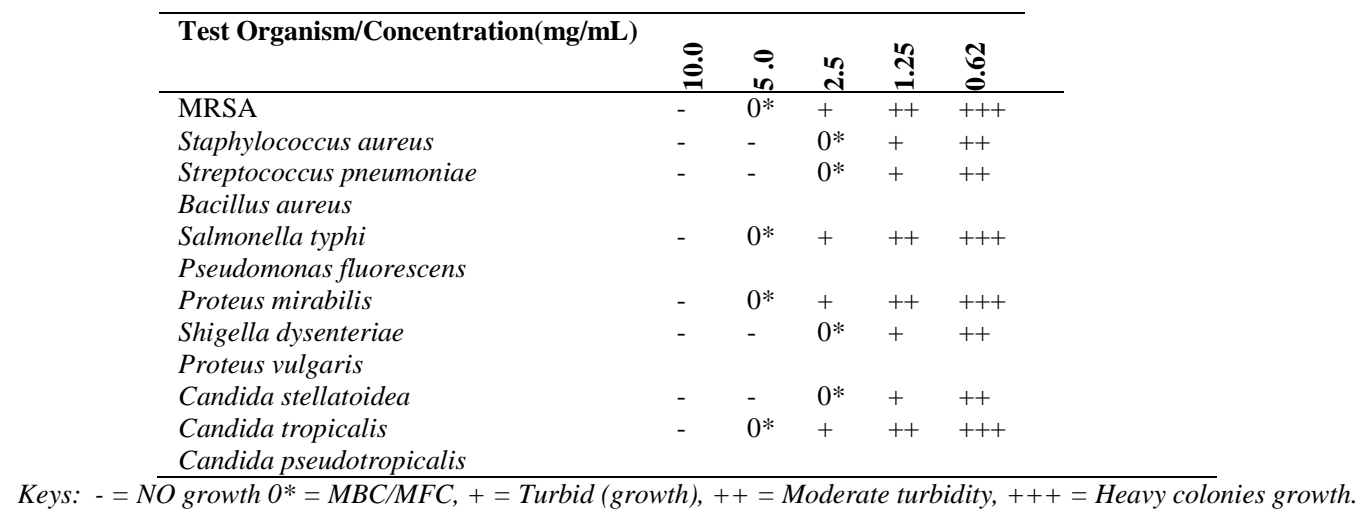

Antimicrobial Screening: Extract showed activity against three gram-positive bacteria (MRSA, Staphylococcus aureus and Streptococcus pneumoniae), three gram-negative bacteria (Salmonella typhi, Proteus mirabilis and Shigella dysenteriae) and two fungi (Candida stellatoidea, Candida tropicalis). Bacillus cereus (gram positive bacterium), Proteus vulgaris and Pseudomonas fluorescens (gram negative bacteria) and Candida pseudotropicalis (fungus) were resistant. Presence of tannins, flavonoids, triterpenoid, steroids and glycosides in plants is responsible for different curative properties of such plants (Hossain and Nagooru, 2011). Triterpenes and glycosides possess a wide range of biological activity including bactericidal, antiviral, fungicidal, cardiovascular and anticancer activity (Mayer et al., 2007). It is significant that the extract was sensitive against MRSA which is resistant to ciprofloxacin (a drug used for the treatment of bacterial infections). The result for zone of inhibition of plant extract against test organisms showed that it was significantly active. Any activity above $12 \mathrm{~mm}$ is taken as a strong activity, although the percentage extracted was low when compared to other reported MAE (Momtaz et al., 2008). Extracts showed a very competitive activity when compared with ciprofloxacin. This may be due to the extraction method used. Microwave assisted extraction has been shown to improve on the inhibition percentage of plant extracts. Kenmogne et al. (2014) reported that analgesic compounds in Ximenia americana obtained by microwave extraction had improved percentage of inhibition when compared with soxhlet and maceration methods. The MIC of extract against Methicillin - resistant Staphylococcus aureus (MRSA), Staphylococcus aureus,
Streptococcus pneumonia, Salmonella typhi, Proteus mirabilis Shigella dysenteriae Candida stellatoidea and Candida tropicalis was $(1.25-2.5) \mathrm{mg} / \mathrm{mL}$, whilst $M B C / M F C$ was $(2.5-5) \mathrm{mg} / \mathrm{mL}$.

Conclusion: This study demonstrated that Ficus exasperata has the potential to be used as a source of antimicrobial compounds; for this reason, isolation and characterisation of the bioactive components from its extracts is ongoing.

\section{REFERENCES}

Adebayo, EA; Ishola, OR; Taiwo, OS; Majolagbe, ON; and Adekeye, BT. (2009). Evaluations of Methanol Extract of Ficus exasperata Stembark, Leaf and Root for Phytochemical Analysis and Antimicrobial Activities. Afr. J. of Plant Sci., 3 (12): 283-287

Amponsah, IK. (2012). Chemical Constituents, AntiInflammatory, Anti-Oxidant and Antimicrobial Activities of the Stem Bark and Leaves of Ficus Exasperata (Vahl). Ph.D. Thesis. Department of Pharmacognosy, Faculty of Pharmacy and Pharmaceutical Sciences, College of Health Sciences, Kwame Nkrumah University of Science and Technology. Pp 11-29

Amponsah, IK; Fleischer, TC; Annan, K., Dickson, RA; Mensah, AY; Sarpong FM. (2013). Antiinflammatory, antioxidant and antimicrobial activity of the stem bark extract and fractions of Ficus exasperata Vahl. (Moraceae). J. of Pharmacog. Phytochem.; 2 (3): 38-44.

Anyam, JV. (2011) isolation and characterization of medicinal principles of Pouteria alnifolia Baker 
Roberty. M.Sc. thesis. Department of Chemistry, Ahmadu Bello University, Zaria.

El-Haway, SS; Wassel, GM; El-Menshawi, BS; Ibrahim, NA.; Mahmoud, K. and Ayoub, MM. (2012). Antitumor and antioxidant activity of Ficus elastic Roxb and Ficus benghalensis Linn. Family Moraceae. World Appl. Sci. J. 19 (11): 1532-1539

Hossain, MA; Nagooru, MR. (2011). Biochemical profiling and total flavonoids contents of leaves crude extract of endemic medicinal plant Corydyline terminalis L. Kunth. Pharmacog. J. 3(24), 25-30.

Idris, A., Aliyu, AB., and Oyewale, AO. (2019). Phytochemical screening and antibacterial activity of Centaurea senegalensis growing in Nigeria. $J$. of Appl. Sci. Environ. Manage. 23(6), 1087-1092.

Iombor, TT; Anyam JV. (2015). Epicarp of the Fruit of Landolphia owariensis is Rich In Medicinal Phytochemicals and has Broad Spectrum Antimicrobial Potential. Intern. J. of Curr. Res. in Chem. and Pharm. Sci., 2 (5): 82-90

Jamuna BA., Ravishankar RV; Pradeepa VS. (2011). Evaluation of the Antimicrobial Activity of three Medicinal Plants of South India. Malays. J. of Micro. 7(1): 14-18

Julius, OO; Oluwasusi, VO. and Ibiyemi, MF. (2020). Antibacterial and Phytochemical Screening of Leaf and Seed Extract of Ficus exasperata. J. of Compl. Altern. Med. Res., 11(4): 47-55.

Kenmogne SB., Ngassoum M., Tchatchueng JB., Vardamides JC; Dongmo A. (2014). Microwave Assisted Extraction of Analgesic Compounds of the Root of Ximenia Americana (Oleaceae). Res. J. of Chem. Sci. 4(7):7-10

Lawal, IO; Borokini, TI; Oyeleye, A., Williams, OA, Olayemi, JO. (2012). Evaluation of Extract of Ficus Exasperata Vahl Root Bark for Antimicrobial Activities against Some Strains of Clinical Isolates of Bacterial and Fungi. Intern. J. of Modern Boty., 2(1): 6-12

Muktar, B., Bello, IA., and Sallau, MS. (2018). Isolation, characterization and antimicrobial study of lupeol acetate from the root bark of Fig-Mulberry Sycamore (Ficus sycomorus LINN). J. of Appl. Sci. Environ. Manage. 22(7), 1129-1133.

Momtaz, S., Mapunya, BM., Houghton, PJ, Edgerly, C., Hussein, A., Naidoo, S., and Lall, N. (2008). Tyrosinase inhibition by extracts and constituents of Sideroxylon inerme L. stem bark, used in South
Africa for skin lightening. J. of ethnopharm., 119(3), 507-512.

Nnamonu, LA., Tor-Anyiin, TA; Ugbenyo, NO; Anyam JV. (2016). Isolation and Characterization of $\alpha-$ Amyrin from Stem Bark of Ficus exasperata (Vahl). Biotech. J. Intern. 16(4): 1-7

Noce, A., Di Daniele, F., Campo, M., Di Lauro, M., Pietroboni Zaitseva, A., Di Daniele, N; Romani, A. (2021). Effect of Hydrolysable Tannins and Anthocyanins on Recurrent Urinary Tract Infections in Nephropathic Patients: Preliminary Data. Nutrients, 13(2), 591

Mayer, A. M., Rodríguez, A. D., Berlinck, R. G., and Hamann, M. T. (2007). Marine pharmacology in 2003-4: Marine compounds with anthelmintic antibacterial, anticoagulant, antifungal, antiinflammatory, antimalarial, antiplatelet, antiprotozoal, antituberculosis, and antiviral activities; affecting the cardiovascular, immune and nervous systems, and other miscellaneous mechanisms of action. Comparative Biochemistry and Physiology Part C: Toxic. Pharmac. 145 (4), 553-581

Suleman, M., Khan, A., Baqi, A., Kakar, MS., and Ayub, M. (2019). 2. Antioxidants, its role in preventing free radicals and infectious diseases in human body. Pure and Applied Bio. (PAB), 8(1), 380-388.

Ugbenyo NO. (2017). A triterpenoid from stem bark extract of Ficus exasperata (Vahl). M. Sc. Thesis. Department of Chemistry, College of Science, Federal University of Agriculture, Makurdi. pp 2930 .

Ughachukwu, PO; Ezenyeaku, CCT; Ezeagwuna, DA; Anahalu, IC. (2012). Evaluation of anti-bacterial properties of ethanol extract of Ficus exasperata leaf. Afri. J. of Biotech. 11(16), 3874-3876

Uzama, D., Abdullahi, S., Okeniyi, SO., and Adeyemi, MA. (2018). Antimicrobial Activities and Phytochemical Properties of Ficus exasperata Root Extracts. J. Chem. Soc. Nig., 43 (2). 201-207 